Historia Slavorum Occidentis

2021, nr 2 (29)

ISSN 2084-1213

DOI: $10.15804 /$ hso2 10210

Wojciech JasińsKi (Poznań)

ORCID: 0000-0001-8906-6177

\title{
Późnośredniowieczne Czechy z polskiej perspektywy, czyli Bogusława Czechowicza rzecz o rządach króla Władysława II Jagiellończyka [Bogusław Czechowicz, Idea i państwo. Korona Królestwa Czech w latach 1457-1547, t. IV: Król i stany, cz. 1: Siła słabości? Długie późne rzq̨y Władysława II, Quaestio, Wroctaw 2018, ss. 30o]
}

Książka autorstwa opolskiego historyka i historyka sztuki to kolejna, już czwarta, część wielotomowej autorskiej serii pt. „Idea i państwo Korona Królestwa Czech w latach 1457-1547" wydawanej przez wrocławską oficynę Quaestio. Otworzył ją tom pt. Historiograficzny gorset. Korona Czeska oczami pokoleń badaczy, w którym Autor szczególowo pochylił się nad dotychczasowym dorobkiem historiografii w sprawie dociekań nad głównym przedmiotem całej serii tj. ideą i funkcjonowaniem prawno-polityczym ziem Korony Królestwa Czeskiego (powołanej w tej formie prawnej do istnienia przez „otca vlasti”, cesarza Karola IV w 1348 r.) w latach od 1457 do 1547, tzn. od końca panowania Władysława Pogrobowca przez rządy Jerzego z Podiebradów, Władysława II Jagiellończyka, Ludwika II Jagiellończyka aż do panowania Ferdynanda I Habsburga ${ }^{1}$. Następna część, zatytułowana: Sic noster rex Jiř́ík czy

\footnotetext{
1 B. Czechowicz, Historiograficzny gorset. Korona Czeska oczami pokoleń badaczy, Wrocław, 2017, ss. 178 [t. I].
} 
occupator regni Bohemiae? Rządy w Koronie Jerzego $z$ Podiebradów ${ }^{2}$, odnosi się do okresu od panowania Jerzego z Podiebradów aż do ogłoszenia czeskim królem Macieja Korwina i podziału na Królestwo Czeskie znajdujące się pod władzą husyckiego króla i pozostałe ziemie Korony (tj. Morawy, Śląsk, Łużyce Górne i Dolne), które uznały zwierzchnictwo węgierskiego monarchy. Trzecia odsłona została poświęcona śmierci króla Jerzego i wyborowi Władysława Jagiellończyka na tron czeski. Autor przede wszystkim skupia się tutaj na władzy Macieja Korwina na Morawach, Śląsku i Obojgu Łużyc i panowaniu Władysława w Królestwie Czeskim oraz wzajemnych zmaganiach dwóch czeskich królów, próbach pojednania i znalezienia modus vivendi w tej niezwykłej sytuacji ${ }^{3}$. Seria nawiązuje do wieloletnich badań autora nad dziejami czeskimi: „Wielotomowa epopeja jest podsumowaniem blisko 30 lat badań autora nad historią i kulturą najpierw Śląska, a potem całej Korony Królestwa Czech na przełomie średniowiecza i nowożytności”" Bogusław Czechowicz napisał ponadto swoiste preludium do serii „Idea i państwo” w postaci monografii poświęconej dwóm elementom składowym państwa czeskiego Czechom i Śląskowi - ich relacji wzajemnych, procesów integracji i dezintegracji w kontekście ideologii, polityki i sztuki ${ }^{5}$.

Recenzowany, czwarty tom w serii omawia losy ziem Korony Czeskiej od $1490 \mathrm{r}$. do 1516 r. tj. od śmierci króla węgierskiego i czeskiego Macieja Korwina aż do ostatnich ziemskich chwil Władysława II Jagiellończyka. Książka składa się z pięciu rozdziałów merytorycznych ${ }^{6}$, z których pierwszy został podzielony na następujące

2 Tenże, Sic noster rex Jiř́k czy occupator regni Bohemiae? Rządy $w$ Koronie Jerzego $z$ Podiebradów, Wrocław 2017, ss. 253 [t. II].

3 Tenże, Mathias primus Dei gratia rex Bohemiae. Rehabilitacja nieuznawanego króla, Wroclaw 2017, ss. 326 [t. III].

4 Tenże, Idea i państwo. Korona Królestwa Czech w latach 1457-1547, t. IV: Król i stany, cz. 1: Siła słabości? Długie późne rządy Wtadysława II, Wrocław 2018, fragment tekstu z czwartej strony okładki.

5 Tenże, Dvè centra $v$ Korunè. Čechy a Slezsko na cestách integrace a rozkolu v kontextu ideologie, politiky a umèní (1348-1458), České Budějovice 2011, ss. 332.

6 Kolejno są to: pierwszy rozdzial „Reintegracja Korony pod jednym berłem”, s. 11-53; drugi „Odnowa autorytetu Pragi a Wrocław”, s. 55-177; trzeci „Potęga stanów”, s. 179-203; czwarty „Abychom se neutiskali, něž spolu byli za jednego člověka jako dobří přátéle. U progu wojny domowej”, s. 205-220; piąty „Znowu problemy z sukcesją”, s. 221-249). Całość poprzedzona jest krótkim „Wstępem” (s. 7-9) oraz równie skromnym objętościowo podsumowaniem („Zakończenie”, s. 251-252), ponadto praca zwiera: „Skróty” (s. 253-256), „Wykaz źródeł i literatury” (s. 257-280), „Spis ilustracji” (s. 281-288), anglojęzyczne streszczenie (s. 289-290), „Indeks osobowy” (s. 291-295) oraz „Indeks topograficzny” (s. 297-300). 
części: 1.1 „Kraje koronne wobec nowego władcy” (s. 11-19), 1.2 „Władca wobec krajów koronnych” (s. 20-27), 1.3 „Jagiellonowie a integralność czeskiej monarchii” (s. 27-38), 1.4 „Próby centralizacji władzy. Reformy monetarne” (s. 38-53). Drugi rozdział podzielono na następujące podrozdziały: 2.1. „Zamek Praski” (s. 55-100), w ramach którego wydzielono jeszcze mniejsze części: 2.1.1. „Archikatedra” (s. 55-66) oraz 2.1.2. „Rezydencja królewska” (s. 66-100); 2.2. „Inne kreacje na obszarze praskiej aglomeracji” (s. 101-111); 2.3. „Wrocławskie dokonania mieszczan i biskupa” (s. 112-139) z podrozdziałami: 2.3.1. „Miasto lewobrzeżne” (s. 112-130), 2.3.2. „Ostrów Tumski” (s. 130-133) 2.3.3. „Wspólna inicjatywa - wrocławski uniwersytet” (s. 133-139); 2.4. „Praga piórem Jana Bechyňki i Wrocław w optyce Barthela Steina” (s. 140-147); 2.5. „Inne królewskie miasta i zamki” (s. 147-177). Trzeci rozdział został podzielony na następujące części: 3.1. „Królewska nieobecność” (s. 179-185), 3.2. „Czas wielkich kodyfikacji” (s. 185-196), 3.3. „Władysławowska konstytucja krajowa" (s. 196-203). W kolejnym rozdziale Autor wydzielił dwie mniejsze części: 4.1. „Miasta królewskie przechodzą do kontrofensywy” (s. 205-215) oraz 4.2. „Ku porozumieniu” (s. 215-220). Piąty i ostatni rozdział monografii składa się z następujących podrozdziałów: 5.1. „Vivente rege” (s. 221-226), 5.2. „Wrocławska wizyta hołdownicza w 1511 roku” (s. 226-228), 5.3. „Między Pragą a Wrocławiem - kutnohorski pomnik idei państwa” (s. 228-241), 5.4. „Z cesarzem w tle" (s. 241-249).

We „Wstępie” (s. 7-9) Bogusław Czechowicz kreśli ogólny zarys czwartego tomu swojej pracy na tle całej serii „Idea i państwo”. Wyjaśnia, że omawiany tom reprezentuje już inny, nowy podział w ramach cyklu i zgodnie z tytułem ma się on skupić na relacji pomiędzy królem Władysławem II Jagiellończykiem a szlachtą zamieszkującą we wszystkich ziemiach Korony Czeskiej od śmierci Macieja Korwina aż do śmierci króla „Bene”. Zaznacza ponadto inne podejście do kwestii pisowni i stosowania w swojej pracy zarówno pewnych czeskich terminów, jak i nazw własnych.

Na początku pierwszego rozdziału Autor prezentuje bogatą panoramę wydarzeń po śmierci Macieja Korwina. Uwagę zwrócił na Władysława Jagiellończyka, który po zgonie swojego oponenta i pretendenta do objęcia władzy nad całością ziem Korony Czeskiej skorzystał z okazji, jaką przyniosła mu śmierć węgierskiego monarchy. Kiedy opustoszał tron, pojawiło się kilku pretendentów do zajęcia na nim miejsca jako koronowany monarcha, co opisał w swojej pracy opolski historyk. Jan Olbracht, młodszy, rodzony brat czeskiego króla, próbował również swoich sił w zdobyciu władzy nad Dunajem. Autor szczegółowo patrzy na prawne losy Moraw, Śląska, Łużyc Górnych i Dolnych w kontekście ich oficjalnego związania z Królestwem Czeskim, 
a wcześniejszymi zależnościami prawnymi od Węgier, zwłaszcza w świetle umowy ołomunieckiej zawartej przez królów Władysława i Macieja. Bogusław Czechowicz pokazuje, zwłaszcza przez przywoływanie źródeł z epoki, zawoalowane prawno-polityczne losy ziem Korony Czeskiej i udowadnia, że dążenia historyków do uporządkowania zastanej rzeczywistości historycznej mogą kosztować wiele wysiłku. Czy da się ją klasyfikować w zgodzie z pomysłami dzisiejszych historyków? Autor jasno pokazuje, moim zdaniem, że historia toczyła się na swój sposób wielotorowo. Z jednej strony wraz z opolskim historykiem śledzimy losy Królestwa Czeskiego, z drugiej przyglądamy się losom Śląska, z kolejnej spoglądamy na to, co działo się na Morawach. Ponadto Autor pamięta i o obojgu Łużyc. Wszystkie te powyższe płaszczyzny nie pozostają wyizolowane i odseparowane od siebie przez Autora, który wskazuje na łączące je ze sobą wspólne elementy.

W podrozdziałach pierwszym i drugim opolski historyk przyjrzał się wzajemnym relacjom między krajami koronnymi a monarchą, zarówno od strony poszczególnych ziem wchodzących w przeszłości w skład Korony Czeskiej, jak i z perspektywy jagiellońskiego króla. W trzecim podrozdziale Autor szczegółowo przyjrzał się w szerokim ujęciu działaniom Jana Olbrachta, Zygmunta Jagiellończyka i króla czeskiego w kontekście integralności ziem Korony Czeskiej. Bogusław Czechowicz uważa, że ani samemu królowi Władysławowi, ani jego młodszym braciom nie zależało specjalnie na integralności ziem Korony Czeskiej. Władysławowi zarówno objęcie panowania nad Dunajem, jak i sytuacja prawno-polityczna po śmierci Macieja Korwina niosły ciekawe i unikatowe możliwości, z których korzystał.

W ostatnim podrozdziale Bogusław Czechowicz omówił temat prób centralizacyjnych podejmowanych w różnych ziemiach Czeskiej Korony. Ponadto pisał o przemianach monetarnych, jakie zachodziły wówczas na ww. ziemiach. Śląskie ziemie często nadawał na mocy swojego węgierskiego tytułu królewskiego, a nie czeskiego. Potrafił też bardzo niejednoznacznie i enigmatycznie pisać o tych kwestiach prawnych. Pokazuje to, jak niezwykle skomplikowanie i niejednoznacznie wyglądała wówczas sytuacja prawno-polityczna w ziemiach Korony Królestwa Czech.

W drugim rozdziale Bogusław Czechowicz poświęcił uwagę zabytkom, jakie wzniesiono w Pradze i Wrocławiu w kontekście relacji do władcy. To niezwykle cenne omówienie ówczesnych zabytków pokazuje, w jaki sposób za pomocą architektury i sztuki prezentowano splendor i chwałę monarchy. Autor omówił przemiany, jakich doświadczył Zamek na Hradczanach na skutek przeniesienia siedziby przez Władysława. Na samym początku po objęciu władzy Władysław urzędował w tra- 
dycyjnym Pałacu Królewskim w Starym Mieście Praskim7. Pałac ten stał się siedzibą królewską za panowania Wacława IV i pozostał nią aż do 1483 r. Wówczas w Pradze doszło do wystąpień i niepokojów na tle religijnym zwanymi Drugą Defenestracją Praską. Na tym konflikcie zyskali kalikstyni. Władysław w ww. roku przeniósł swoją siedzibę na Hradczany tam, gdzie wcześniej rezydowali czescy królowie. Ponadto król zaczął unikać Pragi i chętniej przebywał w Kutnej Horze. Na polecenie Władysława architekt Benedykt Rejt rozpoczął przekształcanie pewnych obszarów praskich Hradczan, w tym wznoszenie słynnej sali władysławowskiej z niezwykłym sufitem. Bogusław Czechowicz omówił zmiany, jakie zaszły w praskiej katedrze z uwzględnieniem malunków ściennych związanych z Władysławem. Dzięki szczegółowym opisom oraz temu, że Bogusław Czechowicz korzysta ze swojego doświadczenia jako historyk sztuki, czytelnicy zyskali szansę dokładnego zapoznania się z zabytkami powstałymi za panowania króla „Bene”. W tym np. zwrócił uwagę na miejsca i drobne zabytki, których zwykły obserwator podczas oglądania mógłby nie dostrzec - np. na wieży słynnego kościoła Panny Marii przed Tynem. Autor nie zapomniał przybliżyć czytelnikom innych miejsc, które zmieniano pod wpływem władcy, jak chociażby kościoła św. Henryka i Kunegundy w Nowym Mieście Praskim. Kolejno opolski historyk ukazał przemiany architektoniczne, do jakich doszło za panowania Władysława we Wrocławiu, w tym w ratuszu wrocławskim i nie tylko. Bogusław Czechowicz przy omawianiu dziejów nadodrzańskiego miasta przypomniał losy pomysłu fundacji Uniwersytetu Wrocławskiego na początku XVI w. Opolski historyk przyjrzał się ponadto innym przemianom architektonicznym związanym z panowaniem jagiellońskiego monarchy np. na zamku w Křivoklácie.

W trzecim rozdziale Bogusław Czechowicz powrócił do bardziej politycznej historii, skupił się przede wszystkim na relacji czeskiej szlachty do monarchy, który objąwszy w 1490 r. węgierski tron, zobowiązał się rezydować na Węgrzech, co skończyło się opuszczeniem Królestwa Czeskiego i tylko kilkukrotnymi do niego powrotami. To dało, moim zdaniem, szansę szlachcie czeskiej na ogromną niezależność w sprawowaniu władzy w momencie nieobecności monarchy, z korzyścią dla rozwoju samego Królestwa. Podobną szansę otrzymały Morawy, Śląsk, Łużyce Górne i Dolne. Uważam, że niestety szlachta wszystkich ziem Korony Czeskiej w większości nie wykorzystała tej szansy dla ich rozwoju i pomyślności. Coraz istotniej wzmacniała swoje znaczenie polityczne i poszerzała swoją władzę, wikłając się przy tym w kolejne konflikty i pogłębiając już istniejące, o czym pisze Bogusław Czecho-

7 Dzisiaj znajduje się tam Miejski Dom Reprezentacyjny (czeski: Obecní dům). 
wicz. Autor wnikliwie przyjrzał się skutkom wypełnienia takiego zobowiązania przez Władysława, opisując, jakie skutki z tego wyniknęły dla losów Królestwa Czeskiego, Śląska, Moraw i obojga Łużyc. Wskazał on z jednej strony na znaczący wzrost znaczenia szlachty w przestrzeni publicznej, jak i próby poszerzenia jej wpływów na inne części składowe Korony Królestwa Czech. Czytając pracę Bogusława Czechowicza, zacząłem się zastanawiać, czy może król Władysław do pewnego stopnia nie należał jednak do tak słabych władców, jak często widzą go historycy? Po $1490 \mathrm{r}$. zarówno w Królestwie Czeskim, jak i na Śląsku dochodziło do bardzo żywych i zaciekłych sporów pomiędzy różnymi stanami. Często konflikt zachodził tak daleko, że monarcha musiał interweniować, ponieważ tylko on mógł zakończyć konkretną waśń i czynił to. Funkcjonował jako ostatni szczebel możliwości rozstrzygnięcia sporu/konfliktu/waśni. Opolski historyk omówił także niezwykle istotne zjawisko prawne, jakie rozwijało się w czeskich ziemiach, a mianowicie przeprowadzania wielkich kodyfikacji prawnych i zawierania ich wyników w postaci kolejnych ordynacji ${ }^{8}$ (czeskie: zř́zení), które mogły pomóc walczyć z coraz mocniej postępującym wzrostem przestępczości i polaryzacją pomiędzy konkretnymi grupami społecznymi. Szczególne miejsce przeznaczył Czechowicz dla tzw. Vladislavskiego Zemskiego Zř́zení (Władysławowskiej Ordynacji Krajowej). Zwrócił uwagę na bardzo istotne elementy procesu kształtowania się całego aktu prawnego, w tym m.in. na konflikt miast i szlachty, który sprawił, że ostatecznie przedstawiciele miast nie brali udziału w jego spisywaniu i politycznie na tym tracili. Zwrócił uwagę na ważkie elementy samego uchwalenia tego aktu, procesu jego spisywania i kształtowania go.

Czwarty rozdział Bogusław Czechowicz poświęcił nasilającym się sporom przede wszystkim na linii szlachta-miasta. Te ostatnie utraciły tzw. „trzeci głos” na sejmach krajowych, od wielu lat pozostawały w konflikcie ze szlachtą, która dążyła do ich politycznej marginalizacji. Choć w tym czasie, zwłaszcza w obliczu wieloletniej nieobecności króla w kraju, występowały przejawy bardzo silnej eskalacji konfliktu pomiędzy zwaśnionymi stronami, co objawiało się z jednej strony sądzeniem i skazywaniem szlachty przez sądy miejskie, z drugiej zaś szlachta uciekała się do zemsty na mieszczanach. Skrajnym przypadkiem było osądzenie księcia opolskiego Mikołaja II przez miejski sąd i skazanie go na karę śmierci - wyrok wykonano, król zupełnie nie uczestniczył w sądzie, a brat skazanego pozostał w sytuacji bez wyjścia. Opolski historyk opisał również losy godzenia się zwaśnionych frakcji pod koniec życia Władysława.

8 Kodyfikacji prawa. 
Piąty rozdział koncentruje się wokół sprawy sukcesji po Władysławie. Autor przypomnial, jak pokrótce wyglądały losy małżeńskie króla „Bene” - od związku zawartego na odległość z Barbarą, córką Albrechta Achillesa w 1476 r., przez poślubienie wdowy po Macieju Krowinie w 1490 r., aż do ślubu z Anną de Foix-Candale. Z tą ostatnią doczekał się dwójki dzieci - Anny Jagiellonki i Ludwika Jagiellończyka. Czechowicz skrupulatnie omówił starania sukcesyjne, jakie za życia schorowany Władysław podjął dla zapewnienia dziedziczenia przez jego dzieci tronów węgierskiego i czeskiego, m.in.: przeprowadzenie koronacji vivente rege swojego syna Ludwika, i to zarówno na Węgrzech, jak i w Pradze. W drugiej części piątego rozdziału Autor omówił podróż Władysława i jego dzieci do Wrocławia, aby tam węgierski i czeski monarcha mógł odebrać hołd. W trzeciej części B. Czechowicz skierował swoją uwagę ku Kutnej Horze i sztuce, jaka zrodziła się za panowania Władysława, zwłaszcza w tamtejszym kościele św. Barbary, m.in. w postaci herbów, monogramów Władysława i jego syna Ludwika. Na zakończenie rozdziału opolski historyk odnotował działania cesarza Maksymiliana w obliczu narodzin Anny i Ludwika Jagiellończyków i próby kształtowania spraw dziedziczenia władzy po śmierci Władysława. Autor podkreślił, że Maksymilian odniósł sukces w swoich staraniach i związkami małżeńskimi połączył swoje wnuki z dziećmi Władysława. Bogusław Czechowicz uniknął w tym spojrzeniu na kwestię dziedziczenia władzy po Władysławie ryzyka patrzenia na nie przez pryzmat bitwy pod Mohaczem w $1526 \mathrm{r}$. i jej konsekwencji. To, moim zdaniem, bardzo właściwe podejście. Na koniec rozdziału Autor opisał śmierć Władysława i reakcję mieszkańców Pragi na wieść o niej po ponad 44 latach panowania.

W krótkim i zwięzłym zakończeniu opolski historyk skupił się na opinii, jaką Władysław zyskał w oczach potomnych. Przypomniał, że w 2016 r. minęło 500 lat od śmierci Władysława, choć niestety ta rocznica nie wzbudziła większego zainteresowania wśród historyków.

Podsumowując - recenzowaną książkę uważam za niezwykle cenną i istotną do poznania dziejów naszych sąsiadów. Nadzwyczajnie ważna cecha tej pracy przejawia się w pokazaniu zarówno losów historyczno-politycznych ziem Korony Czeskiej, wraz ze zwróceniem uwagi na ówcześnie tworzoną sztukę, jak i przekazu przez nią niesionego. Tak niezwykłą perspektywę zawdzięczamy temu, że Bogusław Czechowicz z jednej strony korzysta z ogromnej wiedzy jako historyk, z drugiej zaś czerpie ze swojego wykształcenia historyka sztuki. Dzięki takiemu połączonemu spojrzeniu, wykorzystującemu osiągnięcia zarówno jednej, jak i drugiej dyscypliny, uzyskujemy o wiele szerszą perspektywę, dającą ciekawy obraz politycznych, prawno-ustrojo- 
wych i artystycznych losów ziem Korony Czeskiej w latach 1490-1516. Liczę na to, że w najbliższym czasie do czytelników trafi kolejny tom serii „Idea i państwo”.

Nadesłano: 14 III 2021

Zaakceptowano: $30 \mathrm{~V} 2021$

Dr Wojciech Jasiński

Wydział Historii

Uniwersytet im. Adama Mickiewicza w Poznaniu

ul. Uniwersytetu Poznańskiego 7

61-614 Poznań

wojciechjasinski@amu.edu.pl 